Volume 12 Number 4, October-December 2018: pp. 346-354. Copyright (c) 2018 FIAT JUSTISIA. Faculty of Law, Lampung University, Bandarlampung, Lampung, Indonesia. ISSN: 1978-5186 | e-ISSN: 2477-6238.

Open Access: http://iurnal.fh.unila.ac.id/index.php/fiat

Fiat Justisia is licensed under a Creative Commons Attribution 4.0 International License, which permits unrestricted use, distribution, and reproduction in any medium, provided the original work is properly cited.

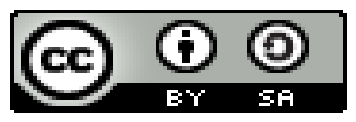

\title{
The Application of Utility in Indonesia Based on the Principles of Utilitarianism
}

\author{
Arlene Agustina \\ University of Tarumanagara, Indonesia \\ agustina.arlene@yahoo.co.id \\ Livia Clarista \\ University of Tarumanagara, Indonesia \\ livia.clarista@yahoo.com
}

\begin{abstract}
Utilitarianism is a principle claiming that the greatest amount of happiness is an end that should exclusively guide all actions of both government and individuals. The fact that people value happiness is considered to be morally right. This principle is pursued by Jeremy Bentham, who believes that the two sovereigns in life are pleasure and pain. It holds an important aspect in law enforcement since it sees what will benefit people the most as the main discussion. Even though there is still some party that opposes or overlooks this view, especially in Indonesia, writers believe that utility is the powerful principle that cannot be set aside. It is needed to be seen as an important aspect on law enforcement so that it can bring happiness and satisfaction to the society.
\end{abstract}

Keywords: Utility, Happiness, Moral, Utilitarianism, and Society.

How to Cite: Arlene Agustina and Livia Clarista "The Application of Utility in Indonesia Based on the Principles of Utilitarianism", Fiat Justisia, 12 (4), (2018).

DOI: https://doi.org/ 10.25041/fiatjustisia.v12no4.1381 


\section{A. Introduction}

In essence, the law, in general, is known to possess three purposes, referring to the well-known Gustaaf Radbruch's theory, which is providing certainty, justice, and purposiveness. Radbruch firstly takes his understanding on the law as "the complex of general precepts for the living-together of human beings." His eventual idea is directed to focus on justice or equality. ${ }^{1}$ The concept of law by Radbruch is then completed with the principle of purposiveness. This principle is used to help define the idea of law itself and its content and is a result from a different view of the state and law. ${ }^{2}$

Measures of usefulness are often interpreted differently from various perspectives and views. Utilization itself has many layers, in various fields, for example, politics, economics, and law. In its development, talking about the purpose of the law is something that is always used as the main topic in every problem solving related to law enforcement. However, in general, the community often focuses on justice and legal certainty, so there are still many cases that do not pay too much attention to usefulness as a legal purpose that must also be upheld in matters of settlement and law rules and enforcement in Indonesia.

Correlating to the theory from Economic Analysis of Law, it is said that the analysis' purpose is to seek the answer of two basic questions about legal rules. Namely, what are the effects of legal rules on the behavior of relevant actors? And are these effects of legal rules socially desirable ${ }^{3}$ In this case, those questions can be used in the term of deciding whether how useful a legal rule to the people, and since one of the questions is specifically focusing on social desire, thus it can also determine the urgency and the importance of applying law usefulness on legal rules and it's effectiveness and efficiency in achieving its end goals. It is also to prevent the rise of social anxiety, where the legal rules and law enforcement should exist to guarantee the lives of the people in the nation to run safely and peacefully.

A British Philosopher, Jeremy Bentham, feels sure of the truth of that human will take action to get as much "happiness" as they could get and lessen the pains. In his book Principles of Morals and Legislations, he declared that by utility is meant that attribute in any object, whereby it tends to produce happiness, pleasure, advantage, or benefit, (all this in the present case comes to the same thing) or (what comes again to the same thing) to ward off the happening of mischief, pain, evil, or unhappiness to the party whose interest

\footnotetext{
${ }^{1}$ Emil Lask, Gustaaf Radbruch and Jean Dabin, The Legal Philosophies of Lask, Radbruch and Darbin, London: Harvard University Press, (1950), pp. 90-91

${ }^{2}$ Ibid., p. 108

${ }^{3}$ Louis Kaplow and Steven Shavell, "Economic Analysis of Law", Harvard Law School and National Bureau of Economic Research, Chapter 25, p.6
} 
is considered: if that party be the community in general, then the happiness of the community: if a particular individual, then the happiness of that individual.

Nature has placed human beings under the governance of two boundless masters, pain and pleasure as what Bentham said. The greatest happiness of the greatest number is the object of all ordinances. Bentham inferred from the principle of utility that, due to all sanction involves suffering and is therefore evil, it ought only to be used so far as its vows to eliminate some greater evil. ${ }^{4}$ The size of "good and bad" from one human act depends on whether the said-action brings happiness or not. Likewise, legislators should be able to produce legal rules that can reflect "justice" for all individuals.

Usefulness is then often associated with happiness, as Bentham has stated, which is then considered as an act and a character. Therefore, actions and characters that bring together the desire of the majority and resulted in happiness and determined as the right thing is called usefulness. In this article would like to explore and focus on how usefulness principle is used to enforce the law and how beneficial it is to be applied in the society through law, especially in Indonesia.

\section{B. Discussion}

\section{The Form of Utilitarianism Application in Indonesia}

Etymologically, Philosophy comes from the Greek word "philo" (in English, it is translated as love) and "sophia" (in English, it is translated as truth), meanwhile according to I.R. Pudjawijatn. " Filo" means love in the broadest sense, which is to want and because a person wants to try to achieve what he/she wants. "Sofia" means wisdom, and by wisdom means cleverness and understanding. By its name alone, Philosophy can be interpreted as a deep understanding of love that comes with wisdom. A love for wisdom must be seen as a form of process, meaning that all efforts of thinking always look for things that are wise, wise in it contain two meanings that are good and right, good is something that is ethical, while right is something that is rational, so it can be concluded that something that is wise is something that is ethical and logical.

Philosophy is divided into three core branches based on nature and ideas developed in the respective area. The three branches are ontology,

\footnotetext{
4 Brian Duignan and John P. Plamenatz, "Jeremy Bentham", https://www.britannica.com/biography/Jeremy-Bentham, accessed on October $19^{\text {th }}$, 2018

${ }^{5}$ Poedjawijatna, Pembimbing Ke Arah Alam Filsafat, Jakarta: Pembangunan, (1980), pp.1-2
} 
epistemology, and axiology. Ontology is the study of what is real; it studies the connection between all types of being. Epistemology is the study of knowledge, human's knowledge in particular. In this case, we are associating utilitarianism with axiology which is the study of value; the investigation of its nature, criteria, and metaphysical status. There are two main parts in axiology, which are: ${ }^{6}$

a. Ethics: the study of values focusing on the human way of behaving and social problem.

b. Aesthetics: the study of value focusing on the idea of beauty itself and concepts that are related to it. Sense, taste, and emotion are what being concerned in the philosophy of art.

Beside the main branches, there are several principles in philosophy; one of them is principal of utilitarianism as discussed on the foreword, which was developed by John David Hume and Jeremy Bentham. The example of the sturdiest and most convincing approaches to regulate ethics in the history of philosophy is utilitarianism. Proto-utilitarian positions can be noticed right through the history of ethical theory. On the utilitarian view, one should increase the good altogether, considered the good of others likewise one's good despite that it wasn't fully segmented until the 19th century. The Classical Utilitarian's, Jeremy Bentham and John Stuart Mill, identified the good with pleasure, so, like Epicurus, were hedonists about value. This is the reason we mentioned about axiology beforehand because they are related to one another to determine a value. The difference between Bentham and Mill is that to Bentham, the person was at the grace of 'enjoyment' and it was accordingly more desirable to be 'a contented pig' than 'unhappy human.' The higher pleasure wasn't assessed by him, insisting that happiness emerging from the witted game of "pushpin" was as fine as that from reading poetry. John Stuart Mill, squabbled that intellectual, cultural, and spiritual pleasures are more prominent merit than the physical pleasures in the eyes of a adequate judge which is a contrast to Bentham's. Mill saw the maximization of some form of welfare happiness as the source of the good. ${ }^{7}$ Utilitarianism also takes utility as the norm which justice concept can be efflorescence since the purpose is to give maximizes utility for everyone. ${ }^{8}$ The purpose of the law is to give the maximum welfare for everyone, and law's evaluation is done based

\footnotetext{
6 Anonymous, "Divisions of Philosophy" https://philosophy.lander.edu/intro/what.shtml, accessed on October $19^{\text {th }}, 2018$

${ }^{7}$ Michael Robertson and Garry Walter, "Utilitarianism as an Ethical Theory", Journal of Ethics in Mental Health, 2 (1), (2007), p.1

8 Anonymous, "Act and Rule of Ultitarianism", https://www.iep.utm.edu/util-ar/\#SSH3aiii, accessed on October $19^{\text {th }}, 2018$
} 
on consequences from the law applications, so law accommodated the regulations of the welfare state. ${ }^{9}$

The utility is based on people's happiness, and that is why it also considered morally right. The question now is whether we can determine moral judgment it right or wrong. In this case, utilitarianism has its answer. Moral questions actually can have objectively true answers; it is one of the benefits gained from the act of utilitarianism. It contradicts with the society who often sees morality as a subjective matter and only based on people's desire and belief. Utilitarianism then proves that there is indeed a method to differentiate which moral beliefs are good and the one that is bad. Utilitarian perspective teaches us how to act based on the decision with actual or predictable available options of various outcomes. Thus, if we can foresee the number of good outcomes as the result of an action, then we can decide whether it is good or bad. Although there are some doubts about the method of measuring the well-being itself, we, do this on a daily basis. If we have two suffering persons and we only have medication for one of them, we can often tell which one is in mild discomfort and which one is in acute pain. Based on this perception alone, we can be confident enough to give the medication to the one with severe pain and bring more of a good result by doing so. It is a very simple example of a case, but it explains that we can have an objectively right answer to the question of what actions are morally right or wrong.

The first phenomenon in utilitarianism principle is Matthew Donnelly case. $10 \mathrm{He}$ was a physicist and had worked with X-rays for 30 years. He then diagnosed with cancer and lost part of his jaw, his upper lip, his nose, and his left hand, as well as two, lingers from his right hand, and is believed as the result of too much exposure. He was also left blind. The physicians that took care of him told him that he had only a year left to live but then Mr. Donnelly decided that he didn't want to continue living with his state right then because he was in continuous pain. One writer quoted, "at its worst; he could be seen lying in bed with teeth clenched and beads of perspiration standing out on his forehead." Mr. Donnelly then asked his three brothers to kill him, perfectly knowing that he was going to die anyway and he didn't want to suffer any longer. While his two brothers refused, one of them did not. The youngest one named Harold Donnelly, who was 36-years-old at that time, brought a 30 caliber pistol to the hospital and shot his brother to death. It was unfortunately based on a true story, and it was heavily questioned whether it was a right or

\footnotetext{
${ }^{9}$ Lili Rasjidi dan I.B Wyasa Putra, Hukum sebagai Suatu Sistem, Bandung: Remaja Rosdakarya, (1993), pp. 79-80

${ }^{10}$ Edogiawerie, Morris \& Fidelia O. Edogiawerie, "The Socio-Ethical Implications of Euthanasia on the Contemporary Nigerian Society", Journal of Culture, Society and An International Peer-reviewed Journal, Vol.5, (2015), p.2
} 
wrong move to be made. However, we might figure that he was inspired by noble belief; his brother was his beloved, and he wanted only took away his grief. Moreover, Matthew had asked to die. All this argues for a lenient judgment.

However, according to the influential righteous tradition especially in Indonesian society, what Harold Donnelly did is unacceptable. He intentionally killed an innocent person. However, utilitarianism takes a very distinct way. It would have us ask: Considering the choices available to Harold Donnelly and what is more favorable to the situation itself. Also, we also have to consider Matthew's desire itself. If Harold does not kill his brother, his brother will live on, for perhaps a year, sightless, disfigured, and in continuous sorrow. Matthew Donnelly's witness was that he was so sorrowing in this state that he would rather die. The way to escape from this misery is to kill him. Thus, utilitarian have surmised that euthanasia is to relieve pain and suffering, might in such a case, be morally right. ${ }^{11}$

The application of utilitarianism can be found in Indonesia's society as well, even though we might not realize it due to the lack of attention on utility as one of the purposes of the law. Writers believe that some legal actions reflect the principles of utilitarianism. The first example of it is discretion that is done by the law enforcers. Definition of discretion is the power authority conferred by law to act on the basis of judgment or conscience, and its use is more an idea of moral than law, with the meaning as a power or authority to do under the law for consideration and their beliefs and emphasizing moral judgment rather than legal considerations. ${ }^{12}$

In the opinion of Soerjono Sukanto citing the opinion of Roscoe Pound and Lafavre applying discretionary action is necessary in law enforcement, because the discretion is between law, morals, and ethics, so that in law enforcement not only implement the provisions of the law but also must pay attention to the values of social rules and behavioral patterns of society. ${ }^{13}$ It cites the opinion of Sukarton Marmosudjono one of which must be considered in law enforcement is the approach that should be used, such as judicial approach, in this approach a lot of things need to be considered $b$

Because this approach is the most important in law enforcement, therefore, to reach social justice is needed socio-political and sociocultural

\footnotetext{
${ }^{11}$ Ibid., p.189

${ }^{12}$ Muhammad Ikbal, "The Implementation Of Discretion On Criminal Settlement In The Theft Cases", Indonesian Journal Of Criminal Law Studies (IJCLS), 2 (1), (2017), p.5

${ }^{13}$ Nabitatus Sa'adah, "Kebijakan Pengampunan Pajak (Tax Amnesty) Berdasarkan Keadilan Yang Mendukung Iklim Investasi Indonesia”, Jurnal Masalah-Masalah Hukum, 46 (2), (2017), p.182
} 
approach, so it can support the development and unity of the nation, and sense of social justice can be fulfilled in the life of nation and state.

One of the examples of discretion in real life is when the police are allowing transportation to use Transjakarta's line, also known as a busway, if there is some severe traffic happening. The law forbids that action, thus there is a punishment if we ever do that. But due to the mutual interest of the people who are stuck in the traffic, law enforcers usually permit transportations to use the busway to reduce the traffic. Also, in some cases, particularly for ambulances and fire trucks, which are on their duty, are also allowed to use the road that is closed for public use. From this, we can conclude that discretion is one of the real enforcement that put society's interest more than legal rules.

The next example is tax amnesty. Based on the latest version of the bill, tax amnesty is free-pass for the taxpayers to pay their disclosed and unreported incomes in their previous tax periods without having to face any penalty. During this period, taxpayers only need to pay a special amount of tax set by the government in exchange for the remission given to them for the liability. Three values of law are justice, certainty, and utility must run altogether, unfortunately, in reality, we often find that one value is more dominant than the others that it tends to overlook the other values. The tax amnesty is reputed to be in contradiction to the obedient taxpayers' justice, however, if we look from utility phrase, the tax amnesty in the long term will fix the revenue of our tax income, also enhance the taxpayer's will to pay the tax and also, expose the hidden assets belonged to the taxpayers. ${ }^{14}$

The other examples of the application of utilitarianism are the existence of GOJEK Indonesia. It is well-known that GOJEK was operating without any legal rules underlying its management before until recently the government made a Minister' Regulation Number 108/2017 as per request to ensure the safety of both the workers of GOJEK (as in motorcycle taxi drivers) and GOJEK customers themselves. The reason behind it is clear, which is the fact that GOJEK Indonesia manages to fulfill what the society's needs and desire by organizing an online-based service and facilitates people's needs. We also know that before, many sides oppose GOJEK, and also it doesn't complement the existing legal rules, but they soon realized that it actually brings usefulness to society. The existence of GOJEK has helped to improve the welfare of motorcycle taxi drivers who have non-permanent income and also provide affordable transportation and fares for customers. Therefore, GOJEK is continuously operating until now, for the sole reason because it brings the majority of the people the satisfaction.

${ }^{14}$ Ibid., p.187 


\section{Conclusion}

To sum up, utilitarianism is one of the philosophical principles that focuses its studies on utility, which put people's happiness forward. The basic principles of utilitarianism by Jeremy Bentham is to recognize the rudimentary role of sorrow and enjoyment in life, agree or disagree of a deed on the basis of the quantity of sorrow or joy brought about ("consequences"), equates the joy with the delightful and evil with pain, and to asserts that pleasure and pain are capable of "quantification"-and accordingly to scale. Utilitarianism also can be correlated with axiology because both discussed value (what is right and what is wrong). The form of this principle in Indonesia can be found in real life actions, for example, discretion, tax amnesty and GOJEK Indonesia. Writers think that it is important not to set utility aside in the process of law enforcement, because based on the writers' view and the examples that have been stated as the supporting facts, justice, and certainly can come within the utility.

\section{A. Book}

\section{Bibliography}

Lask, Emil, Gustaaf Radbruch and Jean Dabin. (1950). The Legal Philosophies of Lask, Radbruch, and Darbin. London: Harvard University Press.

Poedjawijatna. (1980). Pembimbing Ke Arah Alam Filsafat. Jakarta: PT Pembangunan.

Rasjidi, Lili dan I.B Wyasa Putra. (1993). Hukum sebagai Suatu Sistem. Bandung: Remaja Rosdakarya.

\section{A. Articles and Journal}

Edogiawerie, Morris \& Fidelia O. Edogiawerie. "The Socio-Ethical Implications of Euthanasia on the Contemporary Nigerian Society". Journal of Culture, Society and An International Peer-reviewed Journal. Vol.5, (2015).

Kaplow, Louis and Steven Shavell. "Economic Analysis of Law", Harvard Law School and National Bureau of Economic Research, Chapter 25. Muhammad Ikbal, "The Implementation Of Discretion On Criminal Settlement In The Theft Cases", Indonesian Journal Of Criminal Law Studies (IJCLS), 2 (1), (2017).

Nabitatus Sa'adah, "Kebijakan Pengampunan Pajak (Tax Amnesty) Berdasarkan Keadilan Yang Mendukung Iklim Investasi Indonesia”. Jurnal Masalah-Masalah Hukum, 46 (2), (2017). https://doi.org/10.14710/mmh.46.2.2017.182-189

Robertson, Michael and Garry Walter. "Utilitarianism as an Ethical Theory". Journal of Ethics in Mental Health. 2 (1), (2007). 


\section{B. World Wide Web}

Anonymous. "Divisions of Philosophy". https://philosophy.lander.edu/intro/what.shtml. Accessed on October $19^{\text {th }}, 2018$.

Anonymous. "Act and Rule of Ultitarianism". https://www.iep.utm.edu/utila-r/\#SSH3aiii. Accessed on October 19 2018.

Duignan, Brian and John P. Plamenatz. "Jeremy Bentham", https://www.britannica.com/biography/Jeremy-Bentham. Accessed on October $19^{\text {th }}, 2018$. 